\title{
Lumen
}

Selected Proceedings from the Canadian Society for Eighteenth-Century Studies

\section{Medical Advance and Female Fame: Inoculation and its After-Effects}

\section{Isobel Grundy}

\section{Volume 13, 1994}

URI : https://id.erudit.org/iderudit/1012519ar

DOI : https://doi.org/10.7202/1012519ar

Aller au sommaire du numéro

\section{Éditeur(s)}

Canadian Society for Eighteenth-Century Studies / Société canadienne d'étude du dix-huitième siècle

ISSN

1209-3696 (imprimé)

1927-8284 (numérique)

Découvrir la revue

Citer cet article

Grundy, I. (1994). Medical Advance and Female Fame: Inoculation and its After-Effects. Lumen, 13, 13-42. https://doi.org/10.7202/1012519ar 


\section{Medical Advance and Female Fame: Inoculation and its After-Effects}

I intend here to examine the multiple significances whereby history is constructed. ${ }^{1}$ Argument, however, will be repeatedly hijacked by narrative - by, that is, a loosely linked series of epic tales which might be horribly called 'The Matter of Smallpox,' in whose finale the human race defeats the variola virus. As a literary critic, I am interested chiefly in how the stories were produced, and in their value as a site for the observation of cultural politics. But the tales themselves are seductive, constantly urging the critic to enter the fray with a story designed to displace and silence all the others.

The closing tale, set in the 1970s, relates the World Health Organization campaign against smallpox. The virus made its final stand in Somalia, where a hospital worker was photographed as the last sufferer in 1977. The WHO sent out a team of investigators, like Noah's dove, to search the world and prove that the enemy was extinct. During this search, a medical photographer in Birmingham, England, died of smallpox from a laboratory. Her mother caught it too, but recovered. The last smallpox epidemic (the smallest on record but with the highest mortality rate) was a product of western medicine. ${ }^{2}$

Nevertheless, much self-congratulation accompanied the announcement of global eradication on 9 December 1979. Celebrations during 1980 included Genevieve Miller's presidential address to the American Association for the History of Medicine, entitled 'Putting Lady Mary in Her Place.' This revisionist piece argues that to celebrate Lady Mary Wortley Montagu (for initiating the smallpox epic by importing inoculation from east to west) is to ignore the 'conditions' which would have produced the same effects without her intervention. It calls the story of Lady Mary a 'parasitic growth around a single fact': although too 'fascinating' to be easily dismissed, she has received (because of her literary connections) credit more properly owed to the medical profession, primarily to Sir Hans Sloane and the Royal Society. ${ }^{3}$

I agree with Miller that we need to re-read the intersection of Lady Mary Wortley Montagu with medical history. Miller, however, while 
contesting Lady Mary's individual agency, leaves institutional agency unexamined. She contradicts the received idea of Montagu as inoculation pioneer (which is in any case growing steadily vaguer and more confused even while Montagu as writer becomes better known), but accepts the received idea of inoculation (or properly variolation, injection with the variola virus) as a primitive and dangerous forerunner of Edward Jenner's vaccination. Most popular sources (the same which credit Lady Mary with its introduction) present inoculation as a temporary respite: less dangerous, at least, than natural smallpox, and a useful stepping-stone to Jenner's breakthrough discovery of risk-free, efficacious cowpox vaccine. ${ }^{4}$

Miller's account, concerned as it is with the nature of historical causation, is nevertheless shaped by ideology as much as by evidence. Looking at variolation as a purely medical matter, ignoring its cultural and political matrix, opens the door to preconceived opinion, even on purely medical questions.

Montagu's reputation, whether medical or literary, whether in her time or ours, has constantly to compete with Pope's portrayal of her as dirty, promiscuous and malignant. The most celebrated of all his attacks is the couplet 'From furious Sappho scarce a milder Fate,/P-x'd by her Love, or libell'd by her Hate.' Two meanings, not one, reside in 'Poxed by her love.' Dozens, perhaps hundreds of people had been smallpoxed by Lady Mary's loving care, in her campaign for inoculation. Pope constructs his venereal insult by reference to her medical fame: a dozen years earlier he had written that poetic immortality would be 'but a due reward' for her benefaction to 'all posterity.' None of his first readers would have missed this point; today it is missed even by his editors. ${ }^{5}$

A fully heroic presentation of Lady Mary's role would stress her particular horror of smallpox. But such feelings cannot have been uncommon. Smallpox was estimated to kill, with singularly horrible pain, disfigurement and stench, one in fourteen of all English people born. Its untimely victims included (as well as royal personages through whom it altered the course of English and European history) two famous women poets, Katherine Philips and Anne Killigrew. Dryden had commented on this coincidence in his elegy on Killigrew, and Montagu had taken note of his comment, adapting it to make a daring poetic claim for herself. $^{6}$

Lady Mary was severely shaken by her beloved only brother's smallpox death at twenty. As a young mother she expressed acute anxiety lest her husband might rent for them a house where a woman she knew had died, with her child, of smallpox. She justified her fear by a slightly apologetic appeal to its being 'gennerally said' that infection might linger in blankets. She would know that medical authorities like Thomas 
Sydenham, her 'Oracle in Physic,' located infection not in contact but in an 'Epidemick Constitution of Air.'"

Eighteenth-century smallpox discourse was gendered: referring to men, it spoke of the danger to life; referring to women, of the danger to beauty. Montagu followed this line in fictionalizing her own close brush with death in 'Satturday, or The Smallpox.' Her poem's speaker, Flavia, displaces any recent fear for her life into lamenting the loss of the empowering beauty which she equates with life.

Within a few months of losing her looks, Lady Mary was on her way to Turkey. Her husband had been appointed British ambassador to the very country whence reports of smallpox inoculation had recently reached the Royal Society in London, written in Latin by men of science named Timonius and Pylarinus. Within a couple of weeks of arriving in Turkey (at Adrianople) Lady Mary sent home a letter (not extant) whose summary included 'Small pox.' Four months later, Timonius (or Emanuel Timoni) was engaged as the Wortley Montagu family physician, and seven months later again Edward Wortley Montagu junior, aged not quite five, was inoculated. ${ }^{9}$

Miller, downplaying Lady Mary's role in authorized medical history, constructs a train of cause and effect which links the scientific correspondence of Timonius, Pylarinus, et al. to the establishment of inoculation in England, but never intersects with Lady Mary's fortuitous, untrained actions. This separation, I believe, is historically unlikely: more probably Lady Mary acted in concert with the 'official' line of medical advance. Though barred from the Royal Society by her gender, she had been attended through smallpox by three Fellows of the Society, and this too at around the time that the Society received one of its reports of Turkish inoculation practice. Surely she would have heard of this from her physicians, and would (like Charles Maitland, surgeon on the Wortley Montagu embassy) have reached Turkey ready primed with scientific curiosity. She addressed her actual 'Smallpox' letter (though not her later edited version) to her father, whose good friend Samuel Garth was one of her doctors and probable informants. The edited copy, which alone survives, presents inoculation not as an exotic marvel but as a low-key, simple act of collaboration with nature. ${ }^{10}$

Miller makes a more fundamental error in assuming the superiority of medical over lay models of smallpox. Medical opinion was on the one hand still haunted by humours theory, and on the other chary of assumptions which lacked empirical proof. It therefore, mistakenly, rejected the 'generally' felt fear of smallpox blankets. Nor could doctors accept the popular opinion that one attack conferred immunity. They cited the few allegedly documented second attacks, which lay people ignored as they advertised for servants who had had smallpox (and so would be im- 
mune). Maitland, who inoculated Lady Mary's children, was apparently amazed to find the inoculated disease was infectious; she, on the other hand, assumed that this would be the case. ${ }^{11}$

My aim is not to reactivate the past heroinizing of Lady Mary. Her son was not the first Western inoculee in Turkey, though her daughter was the first in England - after an unexplained three years' gap from her return home. I hope to trace the interweaving of her influence with those of Princess Caroline, of self-selected medical and journalistic professionals, and of apparently extraneous contemporary events and processes.

Lady Mary's case demonstrates how hard it is to locate any contribution to scientific advance outside the institutions of science, in the actions of individuals excluded by gender, race, class, or education. Miller's project of investing authority exclusively in the professionals curiously replicates part of the inoculation debate of the 1720s. The first English advocates of the practice gender it as male. Many assign agency in the inoculation of his [sic] 'son and heir' to the British ambassador (who was in fact absent on diplomatic business over the whole period) and avoid any mention of his wife. She, however, assumed her own agency. Her final brief bulletin concludes, 'Your Son is very well; I cannot forbear telling you so, thô you do not so much as ask after him. ${ }^{12}$

In the same spirit, advocates call the leading practitioner in Turkey 'an old Greek' (erasing gender and suggesting the classical) while an opponent writes 'some Old Greek Woman.' Lady Mary mentions 'a set of old Women who make it their business to perform the Operation' and later the 'old Nurse who is the General surgeon upon this Occasion at Constantinople. ${ }^{13}$ Several propagandists for the practice refer to the Prince of Wales (the future George II) as its chief patron in place of his wife, Princess Caroline. In fact the prince's involvement was minimal: the princess conferred with Sloane (according to his own account) before approaching the king. ${ }^{14}$

It was opponents of the new practice who laid stress both on its oriental or Islamic origin and on its female associations. Their discourse, while taking its stand on professional authority, is riddled with sexism, racism, colonialism. A classic example, among many, is William Wagstaffe, whose title-page enumerates his qualifications (FRS, Fellow of the College of Physicians, physician to the prestigious St Bartholomew's hospital), yet whose rhetoric of superiority and exclusivity relies even more heavily on rank, nation and race than on professionalism.

Physicians, I shou'd think, cannot with Prudence give into any thing which is the peculiar Subject of their Profession, merely because it has been cry'd up by those who are no Physicians, and have not the least Knowledge of Distempers. 
The Countrey from whence we deriv'd this Experiment, will have but very little Influence on our Faith, if we consider either the Nature of the Climate, or the Capacity of the Inhabitants; and Posterity perhaps will scarcely be brought to believe, that an Experiment practiced only by a few Ignorant Women, amongst an illiterate and unthinking People, shou'd on a sudden, and upon a slender Experience, so far obtain in one of the Politest Nations in the World, as to be receiv'd into the Royal Palace.

Those from whom we borrowed it, cannot give any tolerable relation of the Fact.... Those again who brought it to us, are... little capable of Judging of the Nature of the Case. ${ }^{15}$

Wagstaffe argues that English superiority makes this alien import inappropriate: English people have more luxurious, richer blood, so, he implies, they need a richer kind of medicine than this cheap and crude procedure carried out by non-physicians (6). He regularly sets the unqualified (nurses, surgeons, 'private People') in a binary bad-good relationship with physicians.

In pouring scorn on 'some sanguine Traveller from Turkey,' Wagstaffe may make coded mention of Lady Mary, who kept the reputation of her travels alive by regularly appearing in public, as well as in portraits, in (modified) Turkish dress. ${ }^{16}$ Sophia Hume a generation later was unusual in calling her, by name, the devil's agent. Most, though not all, contemporary reference, whether damning or laudatory (except in particular contexts like dedications and the introductory paragraphs of historical narratives), is equally inexplicit: 'some Persons now in London, of known Credit and Reputation... have seen this Practice in Turkey. ${ }^{17}$

Even after Montagu's death, allusions to her medical fame often omit her name. A poignant example is her son's reported exclamation about scientific innovators, 'Good God! how happy are these gentlemen, in having been so serviceable to mankind.' Bearing indelible inoculation scars, he can hardly have forgotten that his long-estranged mother ranked with these gentlemen. Samuel Johnson urged travelling researchers to look beyond 'Christendom' for 'additions to our medical knowledge.... Inoculation, for instance, has saved more lives than war destroys.' From Johnson, a devotee of Montagu's letters from Turkey, this is a personal tribute, but one which is not immediately recognisable as such. ${ }^{18}$

At the height of the struggle, the approving St. James's Evening Post conceals Lady Mary's gender; the attacking Wagstaffe occludes her identity but finds association with the female a handy slur. He casts Timoni as Adam, who 'seems indeed to give entire Credit to what the Woman [i.e. the inoculator] told him' (57-58). Such rhetoric plays on masculinist reaction to the ladies who were crucially active in spreading 
the new practice. Their networking speaks to a feminist historian as it did not to Miller's professional or national position. Of course ladies could not domesticate the practice of inoculation without the apothecaries, surgeons and doctors who mostly performed it; but neither could professionals have done it without patronage and support from clients or parents. Lady Mary led the way in lay-medical co-operation in persuading Maitland to operate on her daughter, and assenting to his stipulation for other medics to attend as observers. Family tradition later held

that the... great physicians deputed by government to watch the progress of her daughter's inoculation, betrayed not only such incredulity as to its success, but such an unwillingness to have it succeed, such an evident spirit of rancour and malignity, that she never cared to leave the child alone with them one second, lest it should in some secret way suffer from their interference. ${ }^{19}$

This seems to incorporate some anti-medical mythologizing. Not all the observers were 'great physicians'; one, James Keith, is listed as a perfumer and apothecary. Having lost several children to smallpox, he was an immediate convert, and begged Maitland 'to lose no time to ingraft the only Son he had left. ${ }^{20}$

Medical personnel had reason to hesitate. Not only might they suffer a drop in income if smallpox were eventually to decline; ${ }^{21}$ they would suffer immediate career failure if they backed a procedure which was then discredited. Physicians who supported inoculation were risking their professional life and living. Parents, it might be argued, were gambling with their children's lives; but a parent who had watched a child die of smallpox would see this gamble somewhat differently.

Maitland was a surgeon, well below a doctor in professional standing. No wonder he wanted witnesses as protection in case of accident. During and after the savage smallpox epidemic of 1721 (social life in London almost ceased; five fairly close friends or relations of Lady Mary died in January and February alone) the College of Physicians issued threats of legal action against two distinct groups of competitors: those practising in high life, and those in low life, including 'Apothecaries [who] go Quacking about in the Office of Physicians. ${ }^{22}$ Not only was the medical faculty divided and stratified; one should not assume that a qualified physician, with his degree from Oxford or Cambridge in the medical theory descending from ancient Greece, would be a safer gamble than a 'quack.' This designation stretched from those with no training but experience to graduates of Leyden and other medical schools far more scientifically advanced than Oxbridge. It is curious that, despite the 
Royal Society's devotion to empirical experiment, in medicine the word 'empiric' remained synonymous with 'quack.'

Royal endorsement was vital in the spread of inoculation. The Princess of Wales had a reputation for concerning herself with scientific advance and with the achievements of women. Lady Mary, who had written to her from Turkey, was much her most likely informant on inoculation. Miller points out that their relationship was cool and guarded, ${ }^{23}$ but that is no reason why they should not respect each other's influence and capability. Personal knowledge, not personal affection, was the key to the networks of information exchange which sprang up around this new medical procedure.

One example will show the impossibility of disentangling Lady Mary's influence from Princess Caroline's: that of an inoculated child who grew to become, in 1754, the first parent to have children inoculated at the Hague. Louisa Isabella Hermelina von Wassenaar, later Countess of Athlone, had a Dutch father (Ambassador to the Court of St James at the time of her inoculation); her English mother was daughter of the governess to Princess Caroline's daughters, and also half-sister of Lady Mary's young stepmother. ${ }^{24}$

The first wave of inoculees, all children, came from various ranks. ${ }^{25} \mathrm{~A}$ high proportion of parents in the early years were personally acquainted with a convinced inoculator, either Lady Mary, or Princess Caroline, or some medical proponent. A high proportion, too, had suffered significant bereavement by smallpox. ${ }^{26}$ From 1721 to 1728 (when the Royal Society ceased keeping records) numbers were small enough for such links to be partly recoverable, through the pioneering statistical work of James Jurin and through his modern editor, Andrea Rusnock. Montagu's letters give few names, and downplay her involvement (see below) ${ }^{27}$

Contemporary records took two forms, each of low status but high visibility in the period's burgeoning print culture: newspapers and pamphlets. The Royal Family's involvement in the story from its outset produced a party-political angle which blended with those of profession, gender, and race. Papers supporting the government supported inoculation; those opposing inoculation were opposition or independent papers. $^{28}$

Princess Caroline's involvement may have been hastened by a dangerous smallpox attack suffered by one of her daughters. According to Sloane's later account: 'to secure her other children, and for the common good,' she 'begged the lives of six condemned criminals' in Newgate prison for experimental inoculation by the experienced Maitland. He again stipulated further authorization: he declined to act till Sloane had consulted a doctor with Turkish experience: not a foreigner, not a mere surgeon, not a lady, but a physician. ${ }^{29}$ 
Plans for the royal Newgate experiment reached the papers on 17 June 1721: without mention of Lady Mary, though a private report bracketed her name with the news. From now on, the secrecy which had surrounded her inoculation of her daughter ceased to be available. From now on, though semi-anonymity was accorded the upper classes, operations were reported and debated. When a brother died of natural smallpox and his sister, inoculated from him, recovered, a report of inoculation death was printed but quickly corrected. Lady Mary urged her sister Lady Gower to add her son to the list, but without effect. ${ }^{30}$

Some newspapers punctuated their first reports of the Newgate plan with reports of alarming military action by the Turks against Christians. Many replaced the Princess by various sources of patriarchal authority: British ambassador, 'some Physicians,' the king, and the Attorney-General and Solicitor-General. The two latter were consulted by George I 'to determine whether he can do it by Law': the monarchy's patronage, that is, was carefully constructed as not despotic but properly constitutional. $^{31}$

On June 24 (with the Turks now damagingly active in Poland) the leading anti-ministerial paper, Applebee's, foreshadowed its untiring anti-inoculation stance by denial: the story, 'inserted by way of Amusement from another Paper, is entirely groundless... no such Representation made to his Majesty... no offer made by... condemn'd Malefactors. ${ }^{32}$ But a month later the report resurfaced, when a top-brass medical deputation visited Newgate to 'treat with' the prospective guinea-pigs, three of each sex. It proved a long-running story: at every step newspapers, soon joined by pamphlets, disputed the facts and fought their battle for hearts and minds. ${ }^{33}$

Readers were avid for scientific information. Four days before Maitland operated in Newgate, Applebee's provided such an account, somewhat garbled and framed in fresh scepticism. It opened:

Now seeing this is an affair very much talk'd of at present, we will endeavour to give our Readers some Light into it, tho' it is to be feared we shall still remain pretty much in the Dark about that Matter. It is an Invention that had its Rise among the Populace, who were neither Men of Fortune, Character, or Learning.

It concluded with a racist slur on Jacob à Castro Sarmento, author of the first, newly-published inoculation treatise, inviting readers to say with Horace, 'Credat Judxus Apella, non ego' - to reject the testimony of a foolishly credulous Jew. ${ }^{34}$ Further trivializing the issue, it likened it to a concurrent newspaper dispute: over a wager about a pony climbing a spiral staircase! 
A week later, the experiment over, it switched from race to rank, suggesting that the felons might hoodwink the experimenters 'by pretending that they have never had the Small-Pox, when perhaps they have had them.' The next issue (along with a strongly anti-semitic item) deduced from the experiment's benign outcome that 'any Person that expects to be hang'd may make Use of it, if they please: As for that material Question (viz.) WHO ELSE WILL DO IT, that we cannot, at present, give an Answer to' (August 12,17).

Before the Newgate experiment uncovered in the London press this strain of prejudice against Heathen, Turk and Jew, a parallel story from New England had run its course from start to finish. In this the racist flavour was anti-African. Boston, hit by the same 1721 epidemic as London, embarked on inoculation on the basis of the same two sources of testimony: scientific and popular. The scientific was, as in London, the Royal Society transactions, in Cotton Mather's copy; the popular in this case was the word of black slaves, specifically Mather's slave Onesiphorus, who had been inoculated at home in North Africa. ${ }^{35}$

Mather trusted his slave, or his academic references, or both; he persuaded only one practitioner to trust him. This was Zabdiel Boylston (like Lady Mary a smallpox survivor), who boldly tried the procedure on his son as well as on two slaves (an adult and a child). He inoculated about 280 people before he was stopped by the authorities, who (in a context of misappropriated documents, virulent pamphlets, transparent misinformation, and racist rhetoric) outlawed inoculation in Boston. The official figure for natural smallpox deaths there between April and 23 July 1721 was 17 ; Boylston's figure was 844 . Boylston believed the city fathers deliberately ensured that only inaccurate (as well as, of course, very delayed) reports should reach London. ${ }^{36}$

In Boston, where inoculation began and ended more quickly than in London, the controversy turned on a binary of race, not a spectrum of rank. In London experiments proceeded hierarchically from felons to charity orphans to princesses and then to princes; networks of the privileged (scientists, wealthy ladies) lent their status to the movement. Newspaper activity was also crucial. Medical events might go unrecorded, like the testing for immunity of one of the recovered and pardoned Newgate guinea-pigs. ${ }^{37}$ Court events were news, like Princess Caroline's census, in November 1721, 'of all the Orphan Children belonging to the Parish of St. James's, Westminster, in order that all those who have not had the Small Pox, may receive them by Inoculation, at her Royal Highness's Expence.' By the time this plan was realised, in March 1722, the press was gearing up to frenzy: horror stories from Boston jostled human-interest on the imminent inoculation of the young princesses. 
This event, on 17 April 1722, was followed in two days by the sudden death of the eminent statesman Lord Sunderland, and two days later again by that of his youngest son (and only surviving son by his current wife), the two-year-old 'Honourable Mr. William Spencer.' This combination of events was sensational. Sunderland (whose first wife had died from smallpox, and whose own face was 'one entire mark' from it) ${ }^{38}$ had personally overseen the recent inoculation of his child - who was at first reported as dying 'of Convulsion Fits,' later of smallpox, and by Applebee's 'of the Innoculations, a new kind of Distemper not known in former Days, and an unhappy Experiment to this young Nobleman, who might in all Probability have liv'd many Years, if this dangerous Operation had not been practis'd upon him.' This issue (April 28) included a virulent editorial (using words like 'unchristian' and 'Murther'), five several mentions of the child's death, and the earliest notice of a move to get inoculation outlawed, as at Boston. The London Journal that day ran a piece on tyranny with Turkey as its paradigm (just as Turkish militarism had run concurrently with the Newgate experiment).

This death (intercut with the illness and convalescence of the young princesses) preoccupied the papers for weeks. Speculation about its cause was intense though mostly more guarded than Applebee's. Two years later, anti-inoculators were still expressing outrage that the deathcertificate of so high-ranking a child should be signed by non-physicians, and alleging that 'three of the most Eminent Physicians in Town' had refused to give the royal surgeon Claude Amyand their signatures. ${ }^{39}$

William Spencer's death was followed exactly a month later by that of another inoculee, a nineteen- or twenty-year-old servant of Lord Bathurst. Even Lady Mary, in an anonymous essay, and Jurin, in his statistical record, cite these two as inoculation casualties. ${ }^{40}$ They were the earliest basis for judging variolation to be risky, the germ of later conviction that vaccination must be safer. Yet it may be wrong to ascribe the servant's death to inoculation, and is almost certainly wrong so to ascribe the child's. The servant apparently had a fever at the date of his inoculation, ${ }^{41}$ which is likely to have been the onset of natural smallpox caught from the already-inoculated Bathurst children. Nineteen days elapsed between William Spencer's operation and his death; his pustules were mostly gone; the postmortem found other causes for his fits. ${ }^{42}$ Most tellingly of all, relatives on both sides of his family went straight on to inoculate other very young children.

During the summer of 1722 (as smallpox raged in provincial towns and inoculation spread proportionately) the opposed forces of pro- and anti-inoculation adopted the tones they were consistently to maintain. Each side of course deplores the other's violent language. But the antis' rhetoric of accusation and emphasis (like Jacobite polemic) purposely 
promotes anxiety and suspicion, while the inoculators' rhetoric of collegiality and moderation follows Locke and the Royal Society in proclaiming Augustan reason. ${ }^{43}$ Opponents attack with hyperbole, advocates with irony.

Paradoxically, this import from a cultural and gender Other is supported by appeal to establishment values, even while it is attacked with multiple snobberies. While its enemies demonize and monsterize it, those who support the innovation seek to endow it with cultural, that is patriarchal, authority.

Demonization demands the standard techniques of misogynist, racist, and other slurs. In Boston the Africans are racially marked as 'False Lyars,' their story too 'blundering and Negroish' for belief. A title-page quotes Pliny on monsters out of Africa. ${ }^{44}$ In England, Francis Howgrave writes of 'Pagan Practice.' Wagstaffe and Isaac Massey, each employed by a prestigious hospital, directly accuse Maitland and other inoculators of milking their patients for profit and touting for government patronage. They liken inoculation to abortion or the South Sea scheme, or call it 'an artificial way of depopulating a Country.' Several evoke fears of murder to pervert the course of inheritance: 'many Persons' with children 'under their Trust and Guardianship' might 'poyson two or three of them in order to come to an Estate. ${ }^{45}$ Edmund Massey gives currency to what he unctuously hopes is a false rumour 'That the Princesses [six months later] are not yet well, nor have enjoyed so good a State of Health since, as they did before their Inoculation.' Wagstaffe ends on the nightmare of inoculators as equally 'sure of a Method of silently communicating any Poyson, as they are in those Nations, the most famous for this artful Practice. ${ }^{.46}$ Guardians, step-parents, regicides, Turks and Borgias coalesce in an all-purpose bugbear threatening the fabric of society. Such discourse the twentieth century might call McCarthyist.

Misogynist anxieties swim in this stew. Complaint is made of 'Closet Pharmacy, Ladies and Old Women.' A possible origin for smallpox is located in contamination of the fotus by menstrual blood. Speculation is indulged about the probable evil effects of inoculation involving a menstruating woman, either as donor or recipient. John Williams cites Eve and the serpent and adds, 'Now, Sir, as I humbly conceive, Inoculation is the thing proposed, the brave alluring yellow Apple. ${ }^{47}$

Class antagonisms are evoked with allegations of both insubordination and oppression. If the Newgate inoculees may be subverters of authority, inoculators may be exploiters of the poor. A 'poor BeggarWoman' is reported as indignantly refusing a bribe to have her baby inoculated: 'I'll leave my Child in the Hands of God Almighty. Let thy Money perish with thee!' The Bathurst servant is depicted as seduced by upper- 
class blandishment: 'he was to have Ten Pounds for undergoing it; but he never lived to receive the Money. ${ }^{48}$

The most celebrated sally in this war was a sermon by the Rev. Edmund Massey (nephew of Isaac) on the text, 'So went Satan forth... and smote $J o b$ with sore Boils....' Already notorious for anti-government sermons (called by the other side 'the mad Ravings of a fanatick Priest, bigotted to Party Tenets'), Massey was preaching by invitation of the Non-Juror Henry Sacheverell when he named the devil as the first inoculator. ${ }^{49}$ It was a stroke of theological genius to locate a scriptural example of Satan, not God, inflicting disease (specifically aimed at making the sufferer throw off his dependance on God), with which inoculation could plausibly be equated. (As Massey observed, no medical hypothesis could more convincingly explain inoculation.)

Massey's extreme arguments help to clarify the ideology underlying resistance to inoculation. Disease, he argues, has two spiritual functions: divine punishment, or divine testing, like that of Job. Fear of smallpox is 'an happy Restraint'; without it humanity would become 'less Righteous.' Inoculators usurp the divine authority and encourage impious self-reliance. Most of these points had already been made in Boston, and were to be made over and over into the days of Jenner: they boil down to a message of unquestioning submissiveness to things as they are. Massey does not discuss the medical aspects, the 'Danger and Uncertainty of it in a Physical way'; instead he recommends from the pulpit the recent Letter to Dr. Freind by Wagstaffe, who came of a prominent non-juring family and was a personal enemy of the inoculator Thomas Dover. ${ }^{50}$

Adversaries of Massey and Wagstaffe display their opposite ideological allegiances. Benjamin Colman (who names Lady Mary and gives a succinct account of her involvement) positions himself theologically by remarking that to blame smallpox mortality on inoculation is the boldest lie since Transubstantiation. ${ }^{51}$ James Baker, comprehensively trouncing Edmund Massey's 'Theologico-Medico-Politico Novelty,' cites the Whig Gilbert Burnet preaching before the royal family as witness to the conspiratorial tendencies of ecclesiastics. Arbuthnot (a friend of Lady Mary, and, unusually, a Tory who favoured inoculation) reproaches Massey for 'distorting those great and solemn Truths of our Holy Religion to ma[i]ntain little Party Interests and fashionable Opinions.' He quotes Mather (writing from Boston and pre-dating Massey) locating the devil in the other camp: 'unhappy Physicians' (i.e. those who banned inoculation) 'poison'd and bewitch'd our People with a blind Rage... very like a Satanick Possession, against the Method of Relief and Safety. ${ }^{52}$

About young Edward Wortley Montagu's inoculation, Maitland adds a detail unmentioned by Lady Mary: his lancet did a better and more painless job on the boy's second arm than the female inoculator's 'rusty 
needle' on his first. Accurate or inaccurate, this detail helpfully distances the professional from the amateur oriental woman. Arbuthnot's dedication to Sloane uses scrupulous Royal Society courtesy to suggest that Wagstaffe lacks the experience requisite for judgement. He grounds a hard-hitting argument on medical reasoning and on grasp of the ideological issues. To facts, dates, testimonies, he adds the royal example. To Wagstaffe's ignorant women and illiterate Turks he retorts that quinine 'was introduc'd of a Sudden, by a barbarous Indian' to a Viceroy seemingly a more convincing as well as bolder tactic than trying, like J. Crawford, to minimize the involvement of the gender Other. ${ }^{53}$

Crawford shares the language of moderation. He rebukes Wagstaffe's 'little Arts' of rhetoric, and judges extremist diatribes will be 'the strongest Vouchers' against their own position. ${ }^{54}$ Thomas Nettleton of Yorkshire, who in 1722 inoculated more people than Maitland, calls his opponents 'many honest well-meaning Persons.' I only wish, that as they act upon a Principle of Conscience, they wou'd have been less busy in raising and spreading false and groundless Reports. ${ }^{, 55}$

Perrott Williams (no relation to John) hopes his readers will 'make a reasonable Allowance for a more than ordinary Warmth of Expression, when they shall have cooly, and without Prejudice' considered the slanders of the other side, 'so directly repugnant to an ingenuous Mind, as not to be expected from a Person of a liberal Education.' The failure of Italy and France to act on reports from Turkey he ascribes to the power of the Catholic Church (reclaiming and reversing Wagstaffe's argument of English superiority). He recalls the derision that greeted medical advances by Harvey, Sydenham, and others, and concludes that for inoculators to expect better 'wou'd be as Absurd, as to suppose Humane Nature daily improving.' Wagstaffe's barbarity, he says, is more like the Circassians than like the polite nation he glorifies. Williams detaches inoculation from the margins to place it at the centre. ${ }^{56}$

The clinching argument for inoculation came not from ideology but from the new science of statistics. Arbuthnot made an attempt in that direction, soon extended and improved by James Jurin (who became Secretary of the Royal Society in late 1721, at the height of the first inoculation controversy). Jurin went back over fifty years of the Bills of Mortality to calculate the death rate from natural smallpox. He counted known inoculations in England to February 1723 as 182, by fifteen operators: doctors, surgeons, apothecaries, a clergyman, and three unnamed amateurs, including a woman. (Next year there were 483 inoculations by 34 operators including two women.) Though doubting that Sunderland's son or Bathurst's servant was killed by inoculation, he calculated their deaths as giving a rate of one fatality in 91 operations. ${ }^{57}$ 
Jurin kept publishing his annual survey till 1727 (after which two more years were covered by J. G. Scheuchzer). He shows how the provinces overtook London in inoculation rates, and disproves the charge that inoculating caused infection and so actually hastened the spread of smallpox. He expresses anxiety lest, when smallpox cyclically decreases, inoculation should decrease too; he advertises for data, and calls for house-to-house canvasses to research the incidence and mortality of the disease. ${ }^{58}$

To Enlightenment data-collection Jurin adds Enlightenment reasoning, but also, implicitly, Enlightenment exclusion. In 1723 he prints letters revealing that inoculation existed in Pembrokeshire, Wales, as 'an immemorial Custom,' 'a common Practice with them time out of mind,' popularly called 'buying the smallpox. ${ }^{, 59} \mathrm{He}$ lists only two of these amateurish operations among his statistics, and leaves unexplored the folk context which would not enhance inoculation's image. He covers Turkey and New England, not Africa. In 1724 he goes case-by-case through nine alleged inoculation deaths, expressing doubt about each. As if recognizing how faulty data can cripple statistical method, he then resorts to rhetoric:

To impose upon the World in any Particular, is disingenuous and base; but to deceive them in an Affair so nearly concerning the Lives of Mankind, is a Wickedness worthy of the utmost Abhorrence and Detestation.... every Gentleman, who has the Honour to serve his Country in the Capacity of a Physician.... will consider, whether it will be for his Reputation, when his Friend and his Patient shall put his Life, or the Lives of his Children, into his Hands, to amuse himself with Theological Disputes and Scruples, whether it be lawful to save them. ${ }^{60}$

Jurin anticipates Miller in claiming inoculation for the male professional establishment.

On each side, the terms of debate equally resist intervention by a woman. Despite one important publication (see below) Lady Mary the leader of society was more active over inoculation than Montagu the author. Her textual elusiveness masks the extent of her involvement; but, once demonstrated, that involvement reveals the limitations of mainstream, unidisciplinary study. Her weapons in cultural struggle were non-professional: her link to Princess Caroline, her extensive social circles, her maternal relationship, and her outsider's eye.

Her comprehensive networking, revealed in the names of early inoculees, began with women of her own age and interests. Sunderland's third wife, Judith née Tichborne, mother of the little boy who died, inhabited such a network. Lady Mary's gossipy letters of this period 
make wholly non-medical mention of her and her sister Margaret (Tichborne) Pulteney, who inoculated a child in 1727. Their sister-in-law Charlotte Amelia (Molesworth) Tichborne, Woman of the Bedchamber to Princess Caroline, inoculated her children, one of whom later became Lady Mary's close friend-by-correspondence. Lady Mary before her marriage had read and circulated the MS poems of Charlotte Amelia's sister Mary (Molesworth) Monck, which on publication were dedicated to the princess. A Molesworth brother, Walter, was to consult Lady Mary on delicate financial matters; to his son she stood godmother, and gave her sumptuous portrait by Jonathan Richardson. ${ }^{61}$

This unstructured web of relationships leads in another direction as well. Sunderland's niece Charlotte (MacCarthy) West, Lady De La Warr, was a friend whom Lady Mary compared with Sappho: 'a Woman of great merit with whom I liv'd in much Intimacy. ${ }^{62}$ She married in 1721 and inoculated her eldest child on 26 May 1722, during the same early phase as Princess Caroline and Charlotte Amelia Tichborne. ${ }^{63}$

The only inoculees whom Lady Mary identified in letters to her sister were the children of their shared friend Lady Binning, and their nephew (their father's heir) and young half-sisters. Otherwise she wrote generally of 'the whole Town' badgering her for help and support. ${ }^{64}$ But often the people whose sexual and other peccadilloes she does report were also parent-inoculators. The same social group furnished both scandal and medical innovation. Conservatively estimated (in view of doubtful identifications, etc.), the Jurin correspondence names twenty inoculees connected with Lady Mary besides those I am about to detail, and the list of names in Miller's Adoption of Inoculation (110) raises that number.

Children were inoculated in the families of at least six of Lady Mary's girlhood friends: Dorothy (Walpole), Viscountess Townshend; Anne (Justice) Thompson of York; Jane (Brownlow) Bertie, Duchess of Ancaster; Lucy (Sherard) Manners, Duchess of Rutland; Anne (Vaughan) Powlett, Duchess of Bolton; and Elizabeth (Colyear) Sackville, Duchess of Dorset. The Duchess of Ancaster had married her husband ten months after his first fiancée, her sister, had died of smallpox, as neither she nor Lady Mary would have forgotten. The Dorset heir was inoculated from the same donor as the Bathurst servant. Bathurst himself, Lord Hervey, Sir Robert Walpole, and the then Lord Chesterfield were among her male friends who had children inoculated ${ }^{65}$ One four-year-old difficult patient, who kept her attendants on the jump by refusing liquid, was the daughter of two of Lady Mary's friends (not married to each other), the young Duchess of Marlborough and William Congreve. Jean Bowes, inoculated at Durham aged 23, belonged to the family of Edward Wortley Montagu's coalmining partner. ${ }^{66}$ Four daughters of George Montagu, 2nd Earl of Halifax (inoculated in 1726), were half-sisters of 
the child who, dying of smallpox with its mother, had spelt the threat of infection to Lady Mary twelve years before.

Besides Durham and York, Lady Mary's immediate influence apparently stretched to Salisbury, where inoculees included four of her Fielding cousins, and members of the Harris family, with one of whom a lasting relationship resulted. The inoculation roll-call endorses her grand-daughter's words: 'all who could make or claim the slightest acquaintance with Lady Mary Wortley used to beg for her advice and superintendence. ${ }^{67}$

The silence of her letters to her sister verges on active concealment. At the time of her daughter's inoculation they are wholly engrossed in a personal problem (a threat of notoriety more damaging than that of inoculation); she says she is as incapable of attending to other things 'as I should be if my house was on Fire.' The month of the Newgate experiment found her still engrossed in this trouble, yet claiming to enjoy 'Indolence and sweetness' at her country retreat. ${ }^{68}$ She was there again in April 1722, when she gave a single sentence to Sunderland's death and the generalized success of inoculation. Unless she wrote between receiving the news of April 19 and that of April 24, this means she suppressed his son's suspected inoculation death. One suspects suppression, too, in her writing during the month of Massey's sermon, 'At this Dead Season 'tis impossible to entertain you with news.' Her comment on her uninoculated nephew's smallpox death deliberately distances and minimizes the opposition as 'some Fools. ${ }^{69}$ It seems that either the letter genre or her relationship with her sister could not carry the tale of struggle which her family was later to preserve. Her self-erasure in the interest of respectability parallels the inoculators' erasure of her and her sex.

Her one known public statement, 'A Plain Account of the Innoculating of the Small Pox by a Turkey Merchant,' is, under the cloak of pseudonymity, almost shockingly outspoken. ${ }^{70}$ No other pamphlet attacks head-on 'the Knavery and Ignorance of Physicians,' or contrasts the Constantinople method (no fees, no preparation, no fatalities, an 'old Nurse,' the scratch of a needle and no more infectious matter than will lie on the needle's point) with the London method (high fees, preparatory purging and alcoholic cordials, professional medics, and a 'vast Quantity' of 'Infectious Matter' inserted in 'miserable gashes'). She claims that the Turkish or female method of 'leaving Nature to her selfe' meets with 'the good successe which generally follows a rational Way of Acting'; the London or heroic-interventionist method has caused two deaths, which she calls murder for money. (Since she accepts that inoculation of any kind caused these deaths, she was probably writing several months before her essay reached print on 17 September 1722; she later exonerated inoculation from blame.) 
Where other inoculators claim nature as their ally, Lady Mary constructs Turkish inoculation as natural but English inoculation as the outrage to nature that its opponents claimed. She eschews the discourse of moderation even while she enlists, like other pro-inoculators, under the banner of reason. Her implied world-view is unique in this controversy: that of a champion of reason who lives not in the rational world posited by her allies, but in the treacherous, misogynist, violent world evoked by her opponents.

It seems her medical premise, though unacceptable to most people, was correct. Arbuthnot, Nettleton and others advise inoculating with small quantities, in small incisions, and seek to limit medication, purging, vomits, blisters and bleeding. In later generations, gentle methods were repeatedly put forward as wholly new alternatives to 'old-fashioned' aggressive interventions and heavy dosing, with no recognition either that these in their day had been English innovations, or that '[m]ercenary calculations' had been a major factor in their popularity. ${ }^{71}$

The procedure's replacement by vaccination was accelerated by the child Edward Jenner's physical sufferings as he was prepared for inoculation. Razzell writes of the crucial impact of technique on the safety of inoculation. ${ }^{72}$ But no professional of the 1720 s entertained the heresy of the oriental originators (and later of twentieth-century vaccinators) of actually omitting purges, vomits, or bleeding. The single female pro-inoculator's class and gender position gave her unusual freedom to criticise forces, powerful in her culture, which stemmed from the concept of cure as a violent expulsion of disease. She alone opposed the westernization of her oriental import. Today her political premise - the serious threat to health posed by over-medicalization — seems as persuasive as her scientific one.

Later family tradition had it:

that in the four or five years immediately succeeding her arrival at home, she seldom passed a day without repenting of her patriotic undertaking; and she vowed that she never would have attempted it if she had foreseen the vexation, the persecution, and even the obloquy it brought upon her. ${ }^{73}$

The obloquy came from women and the lower ranks, but under patriarchal direction. Lady Mary's little daughter, taken along 'to prove her security from infection,' observed 'the significant shrugs of the nurses and servants,' and the open hostility of 'aunts and grandmothers' quoting the authority 'of this doctor or that apothecary.' That daughter's daughter, Lady Louisa Stuart, mentions not only the medical profession ('all... in arms to a man') and the clergy, but also 'the common people' taught 'to hoot at her as an unnatural mother, who had risked the lives 
of her own children. ${ }^{74}$ This hostile limelight, which Lady Mary concealed from her sister abroad, must have been unacceptable to her husband as well as painful to herself.

Against it could be set various forms of perhaps equally unwelcome praise: the embarrassing voices of pamphleteers, ${ }^{75}$ the short-lived approbation of Pope, the mocking, paradoxical, near-sacrilegious celebration of Voltaire's controversial Letters Concerning the English Nation, ${ }^{76}$ and the effusive, gallant flattery of authors in search of a patron. This last style lends itself smoothly to praise of beauty or of wit (Richard Savage, for instance, waxes effusive on Lady Mary and on inoculation, but separately), but becomes ideologically dislocated when faced by unorthodox medical prominence or social courage in a female.

Aaron Hill, in the prime contemporary example of praise for Lady Mary as inoculator, sounds not merely gendered but sexist. He prints her name in full, a noble lady's name being at home in the title of a poem as it was not in a pamphlet. ${ }^{77}$ But he ascribes inoculation-phobic views not to professional men but to 'a pious Old Woman,' or to spinsters who, unmarried owing to smallpox scars, therefore wish this same misery on others. It is ironical that this praise of Lady Mary's inoculation work should gender her opponents as female. Hill adds racism to sexism with a fable likening such women to 'an ugly Indian.' He presents the saving of lives from smallpox as protecting an investment: either that of a parent ('the promis'd Comfort of his Life'), or of the nation ('Many Thousand British Lives... the Use, and Comfort, of their Country'). Except in his peroration, his prose presents male scientists as thus preserving life, Lady Mary as preserving mainly beauty. His poem is equally gallant: the Muses, woman-like, envy her wit till they see her face (he disregards the damage already inflicted on it by smallpox); then, charmed by her beauty, they beg the art of inoculation from Apollo as a gift for her. This fable neatly reduces her from agent to object. ${ }^{78}$

English women's role in inoculation, never accepted as in Turkey, was soon at an end. A 15-year-old Miss Newberry performed Jurin's only recorded instance of self-inoculation, 'having often importuned her Father,' vainly, for more conventional treatment. But Jurin's two practising female operators lasted only a couple of years. ${ }^{79}$ It is doubtful in any case whether Lady Mary would have drawn support from solidarity with women of different rank or background.

She may have been shaken by two more deaths ascribed to inoculation: the eleven-week-old heir of Lord Essex in April 1728, the five-yearold heir of the Duke of Bridgwater in May 1731. Curiously, each was the son of a second wife whose predecessor she knew well. During the 1730s both smallpox and inoculation had lower profiles than in the 1720s. Though Lady Mary was still occasionally mentioned in discussions of 
the procedure ${ }^{80}$ Pope's 'P- $x^{\prime} \mathrm{d}$ by her Love' sounded as the echo of a dormant, though recent, controversy. The notoriety which he newly fastened on her far outdid that of her medical activity. But a new and fierce resurgence of smallpox (ten years after his death and fifteen after her departure from England) brought re-activation of inoculation warfare, and with it the reappearance of her name.

By now the procedure involved entrepreneurs, almost assembly lines; medical progress was an established article of faith, no longer open to question. In 1754 both James Burges and James Kirkpatrick, having read the Sloane MSS, knew it was not the ambassador but his wife who 'carefully enquired into all Circumstances of the Practice,' brought it from Turkey, 'and recommended the use of it to her own countrymen.' Her belonging to a past generation, her absence from England, and the fairly recent printing of some of her poems, all emboldened their lavish, identified praise. ${ }^{81}$ They co-opt her as Muse to their escalation of Hill's national-patriotic, neo-Roman-imperial approach. (This was to become the norm for the discourse of public health; it was à propos inoculation that Bernoulli coined the term 'Civil Life,' for the period during which a person is of service to the state..$^{82}$ )

Both private gain and public zeal relied on the idea of progress: Lady Mary and her generation might serve as forerunners but not as models. Kirkpatrick, who began practising in Charleston, South Carolina, in 1738, self-promotingly spread the impression (erroneous, says Miller) that inoculation had died out in England until he moved there and revived it. He boosted his own method by denigrating such of his predecessors as might obscure his fame; where Lady Mary's contemporary inoculators had ignored her and her gender, he lauded her while ignoring great medical names like Sloane, Mead, Arbuthnot. ${ }^{83}$

This trend accelerated after her death, with the appearance in capitals of her name and that of her daughter, Lady Bute, in a context of fierce brand-name rivalry: the preface to a pro-inoculation sermon by Robert Houlton, 'officiating clergyman' to the second-generation mass-inoculator Daniel Sutton (who, with a whole family of operators and a nationwide spread of approved associates, dominated what would now be called the industry). Houlton enthuses: 'Thousands of subjects, the tender husband, the affectionate wife, fond parents and pious children engrave her name in deep characters on their hearts and will record it forever with gratitude and praise.' (Only Daniel Sutton himself is equally meritorious.) The noble names embellish his sales pitch, while Lady Mary's actual views about inoculation are reactivated but not ascribed. The Suttons urged gentle methods, as she had done. But they claimed these as absolute novelty, maintaining that no-one before had used such modest preparation and small quantity of matter; that inoculation had 
always been incorrect and risky until the 'æra of the Suttonian discoveries' dawned in $1755{ }^{84}$

Female fame for inoculation, then, included being co-opted to bolster the very medical careerism which Montagu's smallpox essay had attacked. Her cynical view of physicians is shared by a striking literary tribute to her in the form of a prose allegory, The Triumph of Inoculation; A Dream (London: J. Payne, 1767). The author, Cudworth Bruch, says he sent her his work 'in the course of an Epistolary Correspondence. ${ }^{.85}$ In it a dreamer-narrator, fresh from inoculating his children, watches the evil goddess Variola routed by the 'new Divinity' Inoculatio. Good and evil are as sharply distinguished as in Montagu's own smallpox essay: evil is supported by the corrupt and mercenary doctors whose 'scurrilous abuse' was 'so plentifully poured upon her Ladyship,' goodness by only 'five or six' doctors. ${ }^{86}$ The new deity, whose approach transforms gothic horrors into sweetness and light, is attended by Health, 'dressed in a Circassian habit,' and ushered in by a female human figure in English dress. The dreamer enquires the identity of this 'benevolent Conductress,' and awakes 'in a transport of joy, with the sound of Montagu! Montagu!' (20) The work remarkably captures the moral reading which its heroine herself gave to the inoculation struggle.

Not the least interesting aspect of this work is its preface's revelation that Lady Mary carried on a medical correspondence with an obscure country apothecary. Apart from her social networks of friends and parents, apart from poets who sang her and polemicists who used her name, she had intermittent access to an Enlightenment discourse among men of learning, mostly, it seems, foreigners. Voltaire (another smallpox survivor) talked with her in 1727 before heroinizing her as inoculating mother and mother of inoculation. About 1727 also, she may have met the young Théodore Tronchin, who was to become Europe's premier inoculator, introducer of the practice in Amsterdam, then in Geneva, and at last to great acclaim in Paris. ${ }^{87}$ On a visit to England, Tronchin was advised by her acquaintance Dr Richard Mead, and paid homage to Pope at his Twickenham villa. Pope's neighbour Lady Mary would be a natural next stop; Francesco Algarotti was also to call on both of them in the 1730s, though by then their enmity was well-known.

Tronchin's visit remains a hypothesis. Even if it took place, it could have exerted only marginal influence on his inoculating activity, which began in 1748. Six years before that, Lady Mary had formed a friendship with a Tronchin cousin in Geneva. This tantalizing and suggestive concatenation is one of several hints that her advocacy of inoculation continued during what have been thought of as her solitary, isolated years abroad. In Italy she continued to note the ways doctors related to their patients; a movement of mothers inoculating their children coin- 
cided with her years in that country, but centred on Urbino and Perugia while she was in the province of Brescia. The only witness to her direct involvement with inoculation while in Italy comes from Bartholomew de Dominiceti, who boasts of discussing the procedure in detail with her in $1749-51 .^{88}$

Lady Mary's medical reputation was high abroad. Continental medical writers, following Voltaire, wrote of her with admiration. Angelo Gatti went further into the gendering of inoculation: he distinguished the success of the gentle, oriental method performed by women ('the voice both of nature and reason... and so it is that women have always gone about it') from the 'complicated and tedious' London innovations which made 'the patients worse, and more of them died.' His practice followed his precept: appealing to the 'great, and especially the ladies,' he set out in "defiance of vulgar opinion and physical authority... to change an operose process into a mere amusement. ${ }^{, 89}$

This unusual approach is shared by James Moore, Director of the National Vaccine Establishment, in his history of smallpox. Though dedicated to Jenner, this credits the 'brilliant' Lady Mary with having 'actually effected a complete revolution in the practice of Small Pox all over Europe.' Nor does it view her achievement merely as femininely ancillary to Jenner's. Moore is unusually ready to acknowledge her contribution: he is as pro-woman as Gatti, as critical of the medical profession as Bruch, and no more a nationalist than Voltaire, Tronchin or Dominiceti. He engages with the multiple fields of social practice as well as with medical history as such, with cultural and even multicultural readings. He uses as frontispiece a print of the Hindu goddess of smallpox, and consistently emphasises the foreign, folk-medicine, and female-administered history of inoculation.

Moore's critique of western medicine is convincingly argued. He notes that it was Nettleton of Halifax who, 'unfortunately... imbued with the old notion of humours,' increased the size of incisions, till 'even Mr. Maitland was at last driven from the Byzantine method of making slight punctures, to this more cruel and mischievous operation,' and finds a historical (though not a scientific) cause for the practice of purging inoculees. He claims specifically 'that in those days all inoculations performed by private gentlemen, monks, and old women, were uniformly successful: and empirics afterwards, were equally fortunate: none lost patients from inoculation, except the regular members of the Faculty'; 'the Bramins in Hindostan, and the females in the wilds of Arabia, gave no medicines to the inoculated, yet the simplicity of this practice was not long preserved in England..$^{90}$

Such insights have not been recently remembered. Miller's standard history of the spread of inoculation in Europe - despite acknowledging 
the role of women as parents, and quoting Matthew Maty in 1750 on the importance of royal backing - systematically belittles the part played by both Lady Mary and Princess Caroline. It explicitly rebukes Lady Mary's 'animosity' towards the medical profession (72-3). It relates the escalation of inoculation from a simple outpatient procedure to something involving elaborate preparation and six weeks in hospital, with no comment on increase in expense and no hint of any possible increase in danger.

Miller in 1957, though she paid lip service to 'historical relativism whereby the forces of current history have predetermined the attitude of the historian towards his [sic] subject and distorted his historical narrative,' still sounded like a doctors' advocate. ${ }^{91}$ Miller in 1980, the year that celebrated eradication of smallpox, moved explicitly to put 'Lady Mary in her place' and reclaim exclusive credit for Sloane and the medical profession. Most contemporary commentators follow her lead. W. F. Bynum, for instance, says Lady Mary introduced ('from 1718') a version of inoculation which he perceives as risky; he credits the Suttons in the 1750s with inventing 'safer, cheaper, and more sensible modifications. $^{92}$

Razzell apart, medical historians today still read like co-opted allies of the first pro-inoculation doctors. It is time those doctors (though deserving of gratitude for services which no others could have performed) were again submitted to legitimate critique. Taken as a group, they evidently took a safe procedure and made it dangerous; they undoubtedly employed, against the sexist, racist discourse of the antiinoculators, an exclusionary rhetoric which denied the contributions of their female, and non-western, and non-professional colleagues. We may have seen the last of smallpox, but not of disputed issues which can be clarified by a less partial reading of medical history.

ISOBEL GRUNDY

Henry Marshall Tory Professor

University of Alberta

\section{Notes}

1 This essay began as a CSECS plenary lecture in October 1992 at St John's, Newfoundland (where I learned from John Crellin that Newfoundland saw the first inoculations in North America). Later versions were given at the universities of Ottawa (December 1992) and Calgary (March 1993).

2 The director of the lab later killed himself (Michael Bliss, Plague: A Story of Smallpox in Montreal, Toronto: Harper Collins, 1991, 270-71). 
3 'Putting Lady Mary in Her Place: A Discussion of Historical Causation,' Bulletin of the History of Medicine, 55, 1981, 2-16.

4 C. Bruce Perry says inoculation was 'of course, by no means devoid of risk' (Edward Jenner, University of Bristol, n.d., 3). Sixty years ago it was 'really astonishing how thoroughly [variolation was] forgotten,' along with 'the generic identity of vaccinia and variola,' 'the intrinsic analogy of variolation and vaccination' (Arnold C. Klebs, 'The Historic Evolution of Variolation,' Bulletin of the Johns Hopkins Hospital, xxiv, 265, 1913, 69). See, however, Peter Razzell, Edward Jenner's Cowpox Vaccine: The History of a Medical Myth (Firle, Sussex: Caliban Books, 1977).

5 'The First Satire of the Second Book of Horace,' 11. 83-4. The standard edition never explicitly recognizes this meaning in either note or introduction. A biographical appendix mentions Lady Mary's inoculation fame without linking it to the couplet (Pope, Imitations of Horace, ed. John Butt, London and New Haven: Methuen and Yale University Press, 1939, repr. 1969, xv-xix, 13, 373). Nor is the link mentioned by W. L. Macdonald (Pope and his Critics, A Study in Eighteenth Century Personalities, London: J. M. Dent, 1951), or by Valerie Rumbold (Women's Place in Pope's World, Cambridge: Cambridge University Press, 1989). Pope wrote of Lady Mary's immortality to Broome, 16 July 1721 (Correspondence, ed. George Sherburn, Oxford: Clarendon Press, 1956, 2: 77).

6 Complete Letters, ed. Robert Halsband (Oxford: Clarendon Press, 1965-7), 1: 330, 3: 311. Early editions of Encyclopædia Britannica vividly describe the physical effects of smallpox. I owe this reference to Marcia Pointon ('Killing Pictures,' in John Barrell, ed., Painting and the Politics of Culture, New Essays on British Art 1700-1850, Oxford: Oxford University Press, 1992, 42).

7 Letters, 1: 181-3, 238-9, 2: 442; Sydenham, The Whole Works, translated from Latin by John Pechy (London: Wellington and Castle, 1669), 118.

8 Essays and Poems with Simplicity, A Comedy, ed. Robert Halsband and Isobel Grundy (Oxford: Clarendon Press, 1977, 1993), 52-53.

9 Letters, 1: 346, 392. The anticlerical Voltaire, in Lettres sur les Anglais, 1733, claims that the Embassy chaplain was the first ecclesiastic to denounce inoculation as unchristian, fitted only for infidels (ed. Arthur Wilson-Green, Cambridge: Cambridge University Press, 1931, 37).

10 Philosophical Transactions Giving Some Account of the Present Undertakings, Studies and Labours of the Ingenious, In Many Considerable Parts of the World (London: W. Innys), no. 29, 1717, 72-82 (for January-March 1714), 393-9 (for January-March 1716); Letters, 1: 338-40. As early as 1700 the Society had heard a report of similar practice in China (Miller, The Adoption of Inoculation for Smallpox in England and France, Philadelphia: University of Pennsylvania Press, 1957, 48-49). Klebs, too, thinks Lady Mary would know of the Royal Society accounts (71). Maitland mentions his prior knowledge in Mr. Maitland's Account of Inoculating the Small Pox (London: J. Downing, 1722), 3. Lady Mary's doctors were Garth, John Woodward (a channel for the Royal Society's first inoculation account), and Richard Mead, who was already a smallpox specialist, who later superintended the Newgate operation, and whose standard De Variolis, 1747, strongly advocates inoculation. An account of Herculaneum probably by Montagu appeared in the Royal Society Transactions, 47 (1753), 150-59. 
11 She would not 'engraft' her infant daughter for fear of its communication to her nurse, who had not had it (James Moore, The History of Small Pox, London: Longman, 1815, 232; Montagu, Letters, 1: 392).

12 Letters, 1: 394.

13 Isaac Massey, Remarks on Dr. Jurin's Last Yearly Account... (London: n.p., 1727), 19; Montagu, Letters, 1: 338, Essays and Poems, 95. Eastern inoculation was female business: Pylarini found a woman operating on Chios; James Porter in the 1750s believed it was introduced to Turkey by one woman from the Morea, whose single successor was a Bosnian woman (Royal Society Transactions, 49, 1755-6, 104).

14 'An Account of Inoculation by Sir Hans Sloane, Bart.,' which John Ranby, royal surgeon, was meant to publish in 1736, but which waited till Thomas Birch read it to the Society in 1756 (Transactions, 49, 1755-6, 516). Miller is sceptical of this source.

15 A Letter to Dr. Freind; shewing The Danger and Uncertainty of Inoculating the Small Pox (London: Samuel Butler, 1722), 4-6.

16 Wagstaffe, 36-37. A print of her in guise of 'The Female Traveller' was publicly offered for sale (though more likely in the 1760s, after her letters from Turkey were published, than in the 1720s). Pointon says that Turkish costumes she imported survive in the Victoria and Albert Museum; also that pictures of her in such dress constitute misrecognition and involve 'the assumption that colonialist power is homogeneous and undifferentiated,' a view I do not share.

17 Hume (a Quaker, oddly allied here with the high-church Edmund Massey), Remarks on the Practice of Inoculation for the Smallpox... 2nd ed., 1767, 45-6; The St. James's Evening Post, 31 August 1721.

181773 (John Nichols, Literary Anecdotes of the 18th Century, London: Nichols and Bentley, 1812-16, iv, 640); 1783 (James Boswell, The Life of Samuel Johnson, ed. G. B. Hill and L. F. Powell, Oxford: Clarendon Press, 1934, rpt. 1971, 4: 293).

19 Maitland, Account (dedicated to the Prince and Princess of Wales), 9; Lady Louisa Stuart, 'Biographical Anecdotes of Lady M. W. Montagu,' Essays and Poems, 36. Maitland says that he asked for two inspecting physicians and that three visited the child 'with the Small Pox rais'd upon her,' as did 'Several Ladies, and other Persons of Distinction' (10); Lady Louisa says there were four medical observers; William Macmichael says three physicians and the family apothecary (The Gold-Headed Cane, 1827, facs. London: Royal College of Physicians, 1968, 63).

20 P.J. and R.V. Wallis, Eighteenth Century Medics (Newcastle upon Tyne: Project for Historical Bibliography, 1988). Mary Wortley Montagu, later Countess of Bute, was inoculated in April 1721, Master Keith on May 11, after bleeding: 'the germ of that 'preparation' which is to play such an important role later' (Klebs, 72).

21 Frederic Slare wrote to Jurin, 'this great Blessing conferr'd on Mankind' will save many a Life, ay but Says the wicked profuse Medicaster it does also deprive the faculty of many thousand pounds; I am perswaded it will do So in time, and that the old Nurses will learn the Operation' (7 June 1724, Royal Society Classified Papers XXIII). I am indebted to Andrea Rusnock for this and other references.

22 Applebee's Original Weekly Journal and The London Mercury, 4 March 1721, Whitehall Evening Post, 25 August 1722. Apothecaries were prohibited from prescribing without reference to the newly revised, official, Latin Pharmacopeia, or London 
Dispensatory; Thomas Dover, attacked by name as a quack, was later defended in print by parents of a child he inoculated (The London Journal, Applebee's, and The Weekly Journal or Saturday's-Post, 11 March 1721, The Weekly Journal, or British Gazetteer, 18 March 1721, The Whitehall Evening-Post, 26 April 1722).

23 Adoption, 77-78, 268. Sloane says Lady Mary wrote from Turkey about inoculation 'to the court' as well as to friends ('Account,' Transactions, 49, 1755-6, 517).

24 Much biographical detail comes from G. E. C[okayne], Complete Peerage, ed. V. Gibbs et al., 1910-59.

25 Newspapers mentioned the following as inoculated between Lady Mary's daughter in April 1721 and the princess's daughters on 17 April 1722: children of James Keith, apothecary, of 'a Noble Duke in Hanover Square,' of a Hertfordshire gentleman, of Lord Battersea, of Mrs Tichborne (bechamber woman to Princess Caroline) and of John Colt near Lombard Street; and several (parents unnamed) who were available for inspection at various London addresses (The London Journal, 26 August 1721, St. James's Evening-Post, 7 December 1721, 9 January and 24 April 1722, The Weekly Journal or British Gazetteer, 9 December 1721, London Gazette, 10, 27 March 1722). These numbered at least a dozen inoculations; many more roughly coincided with those of the young princesses.

26 Of those inoculated in 1722, Lady Elizabeth Berkeley's mother had died of smallpox in 1717, aged 22; so had the young Duke of Bedford's father in 1711, aged 30; so had Lord Middlesex's grandmother in 1691, aged 22. So had Lord Sunderland's first wife in 1698 .

27 By coincidence, the year that statistics ceased publication was also the year that the flow of Lady Mary's letters was halted by her sister's insanity, as well as the year of Pope's first major attack on her.

28 See Michael Harris, London newspapers in the age of Walpole: a study of the origins of the modern English press (London: Associated University Presses, 1987), e.g. 35, 186.

29 'Account,' Transactions, 1755-6, 517. Miller doubts that the young princess's illness was smallpox (Adoption, 81).

30 Philippe-Néricault Destouches, 10 July 1721 (Ira O. Wade, 'Destouches in England,' MP, 29, 1931, 41). The Post Man, 2 December 1721, The St. James's Evening-Post, 7 December 1721, The Weekly Journal or British Gazetter, 9 December 1721, The London Mercury, 16 September 1721; Letters, 2: 26-7. This child later died of smallpox.

31 Post Man, Whitehall Evening-Post, and St. James's Evening Post, 17 June 1721.

32 The London Journal merely denied the involvement of the Attorney General and Solicitor General.

33 'In the vast literature thereby produced it is often exceedingly difficult to find one's way' (Klebs, 72).

345 August 1721; Castro Sarmento, A Dissertation on the Method of Inoculating the Small-Pox, London: T. Bickerton, 1721 (also published in Latin). The St. James's Evening Post, calling Pylarini 'a Jew' (June 17), sounds more neutral. A broadside of 6 June 1724 records a dispute between Castro Sarmento and synagogue elders.

35 Inoculation seems to have begun in Asia and Africa, and was still practised by African tribes in 1913 (Klebs, 70). 
36 Boylston, A Historical Account of the Small-Pox Inoculated in New-England (London: S. Chandler, 1726), 1-4, 39, 57, 62, 5. See also Increase Mather, Several Reasons Proving that Inoculating or Transplanting the Small Pox, is a Lawful Practice (Boston, 1721); Boylston, ed., Some Account of which is said of Inoculating... (Boston, 1721). London reported Boston as wholly satisfied with inoculation in early November, three months after the ban, which took another month to be related. On 3 February 1722 Applebee's took the deaths of 400 (uninoculated) people in a week as demonstrating 'that they have had but bad Luck' with inoculation!

37 She was sent out of London to Maitland's smallpox-stricken practice, to share a bed with a sufferer (Sloane, 'Account,' 517).

38 Quoted in Frances Harris, A Passion for Government, The Life of Sarah, Duchess of Marlborough (Oxford: Clarendon Press, 1991), 82.

39 [John Arbuthnot], Mr. Maitland's Account of Inoculating the Small Pox Vincidated from Dr. Wagstaffe's Misrepresentations of that Practice; with some Remarks on Mr. Massey's Sermon, 2nd ed. (London: J. Peele, 1722), 49-50; Francis Howgrave, Reasons Against the Inoculation of the Small-Pox. In a Letter to Dr. Jurin (London: John Clark, 1724), 53. Arbuthnot interrupts his medical argument for 'Anti-inoculators (a Word more sonorous, and longer by two Syllables than that of Inoculators)' (4).

40 So do many modern historians, though Donald R. Hopkins, following Moore, disagrees (Princes and Peasants: Smallpox in History, Chicago and London: University of Chicago Press, 1983, 49). Ten months later Lady Mary had changed her mind: 'that Experiment has not yet had any ill effect'. I know nobody that has hitherto repented the Operation' (Essays and Poems, 96; Letters, 2: 26, 27).

41 Post-Boy, 24 May 1722, London Journal, 9 June 1722.

42 St. James's Evening Post, 28 April 1722.

43 Cf. Peter Walmsley, 'Dispute and Conversation: Probability and the Rhetoric of Natural Philosophy in Locke's Essay,' Journal of the History of Ideas, 1993, 381-94. Each side, however, suspected the other of inventing names of non-existent allies (Arbuthnot, 64; Sparham Legard, Reasons Against the Practice of Inoculating the Small-Pox, London: Peele, 1722, 29).

44 [William Douglass], Inoculation of the Small Pox As practised in Boston... (Boston: J. Franklin, 1722), 7; Samuel Grainer, The Imposition of Inoculation (Boston: N. Boone, 1721).

45 Howgrave, Reasons Against the Inoculation of the Small-Pox. In a Letter to Dr. Jurin (London: John Clark, 1724), 58; Isaac Massey, A Short and Plain Account of Inoculation. With some Remarks on the main Arguments made Use of to recommend that Practice... 2nd ed. (London: W. Meadows, 1723), 3-4, 6, 17; anon, The New Practice of Inoculating the Small-Pox Consider'd (London: T. Crouch and A. Dod, 1722), 34, 37, 39. Isaac Massey was apothecary to Christ's Hospital, Wagstaffe physician at St Bartholomew's.

46 Edmund Massey, A Letter to Mr. Maitland, in Vindication of the Sermon against Inoculation (London: W. Meadows, 1722), 23-4; Wagstaffe, 45, 39, 68-9.

47 New Practice, 13; Howgrave, Reasons Against, 17-18, 21-2; Castro Sarmento, Dissertation, 35; Williams, An Answer To a Late Pamphlet Intitled, A Letter to a Friend (Boston, 1722), 3-4. 
48 Applebee's, 12 August 1721; the Jacobite Weekly Journal or Saturday's-Post (also known as Mist's Weekly Journal), 5 May 1722; London Journal, 26 May 1722.

49 Massey, The Signs of the Times. A Sermon Preached before the Right Honourable the Lord-Mayor (London: T. Bickerton, 1722: preached 8 December 1721); James Smith, An Examination of the Signs of the Times (London: J. Roberts, 1722), 32; Massey, A Sermon against the Dangerous and Sinful Practice of Inoculation (W. Meadows, 1722: preached at St Andrew's, Holborn, 8 July 1722). Mist hailed this as 'excellent' (July 14). Massey followed up in A Letter to Mr. Maitland, in Vindication of the Sermon against Inoculation (London: W. Meadows, 1722). Sunderland had pressed for Sacheverell's impeachment.

50 Massey, Sermon against Inoculation, 10, 24, 26, 15, 22. He has stylistic affinities with the Rev. Mr Brand in Richardson's Clarissa. Wagstaffe's Letter, dated June 12 (before the royal success and Sunderland disaster), was published after them (advertised August 2).

51 A Narrative of the Method and Success of Inoculating the Small Pox in New England (Boston, London, 1722), 5, 30.

52 Baker's News, 14 and 21 August 1722; Mr. Maitland's Account Vindicated, 4, 47, $58-61,64$.

53 Maitland, Account, 7; [Arbuthnot], Account Vindicated, 1-2; Crawford, The Case of Inoculating the Small-Pox Consider'd... (London: T. Warner, 1722), 7.

54 Crawford, Case, 4, 39.

55 Nettleton, An Account of the Success of Inoculating the Small-Pox (London: J. Baley, 1722), 12.

56 Williams, Some Remarks upon Dr. Wagstaff's Letter... (London: R. Gosling, 1725), preface, $17-18,22-4$.

57 [Arbuthnot], Maitland's Account Vindicated, 18-20; Jurin, A Letter To the Learned Caleb Cotesworth... Containing, A Comparison Between the Mortality of the Natural Small Pox, And that Given by Inoculation (London: W. and J. Innys, 1723), 5, 7-18; An Account Of the Success of Inoculating the Small Pox In Great Britain... (London: J. Peele, 1724), 9-11. See Rusnock, 'The Weight of Evidence and the Burden of Authority: Case Histories, Medical Statistics, and Smallpox Inoculation,' forthcoming. She points out that Jurin ignores all non-fatal damage ascribed to inoculation. In the 1760s Daniel Bernoulli and Jean D'Alembert made further advances in statistics in a dispute on the same topic: see L. Bradley, ed., Smallpox Inoculation: An Eighteenth Century Mathematical Controversy (Nottingham: Adult Education Department, University of Nottingham, 1972).

58 In 1722 London accounted for 63 inoculations; in 1723 it was 68 out of a much larger total. Opposition statisticians compared 3271 smallpox deaths in the Bills of Mortality in 1723 with 2167 in 1722, and ascribed the increase to spreading by inoculation. Jurin reports smallpox and inoculation as decreasing in [1725], and smallpox increasing in 1726 . His statistical expertise improved with the years, and his price went up from 6d to 1s (Account of the Success, 1724, 9-11, 30; An Account of the Success... for the Year 1724, London: J. Peele, n.d.; An Account... 1725, London, 1726).

59 From Perrott Williams, physician, and Richard Wright, surgeon, of Haverfordwest (Jurin, Letter, 1723, 25-31). Slare wrote to him, 'have not the Children done it in Wales?' (7 June 1724, Royal Society Classified Papers XXIII). 
60 Jurin, Account, 1724, 4.

61 Harrowby MS 77, ff. 118-9; newspapers of 24 April 1722; Lady Mary, Letters, 2: 24, 3: 204; BL Sloane MS 406b, 41. I am grateful to Jane Waley, sometime archivist at Sandon Hall, for information about the gift of the portrait. One of the Molesworths transcribed Montagu's Embassy Letters before they were printed (Harrowby MS 259).

62 Letters, 3: 187, 2: 113.

63 The London Journal. This baby and the Tichborne children were reported 'dangerously ill'; since they survived 'the modish Experiment of Inoculation,' this was probably untrue.

64 Letters, 2: 25-6, 49.

65 The Duchess of Bolton was childless, but she had inoculated nephews and a niece. Lady Mary wrote of Bathurst's fickleness; he boasted the constancy of his friendship for her. In Dijon in 1739 she sought out his eldest daughter, no doubt one of 'her' inoculees (Essays and Poems, 242-4; Letters, 1: 20, 23; 2: 143, 145; Lady Elizabeth Cust, Records of the Cust Family, 1898).

66 BL Sloane MS 406b, ff. 42-3, 79, 85. Lady Mary commemorated another Bowes family member in verse (Essays and Poems, 233).

67 BL Sloane MS 403, ff. 25-7; Isobel Grundy, 'Inoculation in Salisbury,' The Scriblerian, forthcoming; Essays and Poems, 36. Miller's list of eminent inoculees includes some in Lady Mary's stratum of society whom I have not pursued; but these selected results from records of 1720s inoculees should demonstrate the high proportion who had (if not close friendship) some link with her more specific than simply moving in the same general circle.

68 Letters, 2: 4-6, 10-12.

69 Letters, 2: 15, 22, 19, 26-7.

70 The Flying-Post: or, Post-Master, 13 September 1722: Essays and Poems, 95-7. Robert Halsband discusses this essay in 'New Light on Lady Mary Wortley Montagu's Contribution to Inoculation,' Journal of the History of Medicine, 8, 1953, 390-405. The 'Turkey Merchant' identity was quickly denied by Isaac Massey. The fierce critique of doctors may have been fed by their unfounded optimism (about what would happen to her looks) during Lady Mary's smallpox attack, and by a vicious wrangle in print between Sloane and Woodward over smallpox cures at the time of her return from Turkey. It may have been during the controversy, not before, that she gave final form to her edited version of her inoculation letter from Turkey, which can be dated only as before Mary Astell's MS preface, 1724-5. In it she fears that doctors have not 'Virtue enough to destroy such a considerable branch of their Revenue for the good of Mankind,' and anticipates their anger if smallpox were conquered (Letters, 1: 339).

71 Mr. Maitland's Account Vindicated, 24; Nettleton, Account, 4; Klebs, 74. Peter Razzell, Lady Mary's medical vindicator today, makes a similar analysis in The Conquest of Smallpox: The Impact of Inoculation on Smallpox Mortality in Eighteenth Century Britain (Firle, Sussex: Caliban Books, 1977). Inoculation medicines relied heavily on mercury and antimony; one was said to include crabs' eyes (George Lipscombe, A Manual of Inoculation..., London, 1806, 18).

72 Conquest, 14, 112. Miller debates John Ranby's claim to have invented the gentle method without reference to Lady Mary's essay (Adoption, 162); many modern 
writers accept Sutton's claim to credit for this 'novelty' (e.g. Richard B. Fisher, Edward Jenner: A Biography, London: Deutsch, 1991, 17).

73 Essays and Poems, 35-6.

74 Ibid.

75 E.g. Slare (an eminent physician who was reluctant to set his own name to his inoculation statement) and Colman ('Appendix' in Perrott Williams, Some Remarks, 26; Narrative, 5).

76 Published in John Lockman's English version, 1733, before its appearance in French. Letter 11 deals with inoculation.

77 Hill, The Plain Dealer, 30, 3 July 1724 . Pope is probably implicated here. Hill flatters Pope too, and in July 1721, with the Newgate inoculation still in the future, Pope (who was, like Lady Mary, in retreat at Twickenham) had commended William Broome's apparently abortive plan to laud her innovation in verse, as 'but a due reward for an action which all posterity may feel the advantage of' (see above, n. 5). Savage reprinted Hill's poem (without its prose context) in Miscellanies, 1726.

78 The line 'Charmed into love of what obscures my fame,' which occurs both in Hill and in Astell's MS preface to Montagu's Embassy Letters, made George Paston suppose that Astell wrote the Plain Dealer essay ('Paston' [Emily Morse Symonds], Lady Mary Wortley Montagu and Her Times, London: Methuen, 1907). But Astell was clearly quoting Hill in order to refute him: she argues strongly against his view that envy is a female trait.

79 Silvanus Bevan to Jurin (12 April 1726, Royal Society Inoculation Papers). A woman near Leicester performed 8 inoculations in 1722, and 4 in 1723: one at Shaftesbury did 5 (all on women) in 1723 (Jurin, 1723, 5; 1724, 11).

80 Bishop John Hough, a distinguished protegé of her old friend Lady Oxford, wrote on 14 February 1737 that he had 'been a great stickler for [inoculation] from the time that Lady M. Wortley brought it to England'. He may have had from her the information that in 'whole kingdoms... the mothers are the operators with perfect safety' (John Wilmot, Life of the Rev. John Hough..., 1812; reprinted in the Gentleman's Magazine, 52: 1, 1812, 47-8).

81 '[W]hen that noble Lady's very pretty poetical Compositions may be overlooked, from the Fluctuation of Language, and thro' the Waste of Time, that excellent Sense, which prompted her to more than female Resolution... shall do unfailing Honour to her Memory' (Kirkpatrick [sometimes known as Killpatrick], The Analysis of Inoculation, London: Millan, Buckland, Griffiths, 1754, 94-5; also Burges, An Account of the Preparation and Management necessary to Inoculation, London: P. Vaillant, 1754, 3-4).

82 Bradley, ed., Smallpox Inoculation, 10.

83 Miller, Adoption, 132-6.

84 Houlton was soon in Dublin as the repository of the Sutton family's secrets, 'commissioned by them, by articles authenticated under the great Seal of London, to regulate and extend their art over the Kingdom of Ireland' - quacking about, as the newspapers of the 1720s might have put it (Houlton, The Practice of Inoculation justified. A Sermon Preached... October 12, 1766, Chelmsford, [1767], v-vi; Indisputable Facts relative to the Suttonian Art of Inoculation..., Dublin, 1768, 10). On the Suttons' reduced preparation and their reversion to Lady Mary's method, see 
Razzell, Conquest, 15-16; Ute Janssen, 'Matthieu Maty and the Adoption of Inoculation for Smallpox in Holland,' Bulletin of the History of Medicine, 55, 1981, 260. Professional rivalries did not cease with the advent of vaccination: Jenner and many of his supporters zealously discredited both inoculation and an unacceptably amateur form of vaccination (see E. Marjorie Wallace, The First Vaccinator, Benjamin Jesty of Yetminster and Worth Matravers and his Family, Wareham and Swanage, n.d.).

$85 \mathrm{He}$ is named as author in a note on the title-page of the Bodleian copy. Born at Benson, Oxfordshire, in 1697, he was an apothecary practising at Wallingford (International Genealogical Index; Wallis).

86 Medical politics here, while echoing Lady Mary's own moral reading of the inoculation struggle, are complex. The 'tender and skilful care' of nurses has often 'rendered the care of the Physicians entirely unnecessary'; evil physicians (who are often directed by equally corrupt apothecaries) are sentenced to bear a humiliating coat of arms bearing a tie-wig with no head in it, 'the supporters, two Ducks, and the motto, quack, quack' $(12,14,19)$.

87 Henry Tronchin, Un Médicin du XVIII siècle Théodore Tronchin (1709-1781) d'après des documents inédits (Paris, Geneva: Plon-Nourrit, Kundig, 1906), 4-7.

88 Letters, 2: 267-8, 423, 487. Inoculating mothers included Urbino women in 1746 or 1749 and the marchesa Buffalini or Bussalini in 1754 (Tronchin, 122-3; A. de Haen, Refutation de l'inoculation, Vienna: Trattaer, 1759, 88; Angelo Gatti, New Observations on Inoculation, transl. from French by Matthieu Maty, London: P. Vaillant, 1768, 27; William Woodville, History of the Inoculation of the Small-Pox in Great Britain, London: James Phillips, 1796, 1: 284-5). Brescia was also home to the leading Italian anti-inoculator, Count Francesco Roncalli. Dominiceti says he has not 'advanced a single fact on [inoculation], much less drawn a conclusion from it, of which I had not the satisfaction to receive the strongest confirmation from her ladyship' (Medical Anecdotes of the last Thirty Years, London: L. Davis, 1781, 431 n.). In his later, English medical career he equalled the Suttons as a self-publicist (Reginald Blunt, In Cheyne Walk and Thereabout, London: Mills and Boon, 1914, 137-55).

89 New Observations, 27, 21; Maty's 'Preliminary Discourse' to it, vii.

90 Moore, The History of the Small Pox (London: Longman, 1815), 228, 233, 234, 247, 253,255 . Klebs cites Moore, gives credit to Lady Mary, and stresses the superiority of low-key methods. But even he attributes early mistakes to 'crude methods,' applauds the 'more scientific, systematic spirit' in 1760s inoculation, and ends with a plea for the honouring of exclusively male, professional names $(73,75,83)$.

91 Pp. 123, 18.

92 'Medicine at the English Court, 1688-1837' in Vivian Nutton, ed., Medicine at the Courts of Europe, 1500-1837 (London and New York: Routledge, 1990), 269-70. 